RYSZARD SELEJDAK, RZYM

\title{
FORMACJA KANDYDATÓW DO KAPŁAŃSTWA W ŚWIETLE NOWEGO RATIO FUNDAMENTALIS INSTITUTIONIS SACERDOTALIS
}

Jednym z najważniejszych zadań Kościoła jest formacja przyszłych kapłanów, którzy owocnie podjęliby zbawczą misję Jezusa Chrystusa Dobrego Pasterza we współczesnym świecie, pełnym różnorodnych wyzwań. ${ }^{1} \mathrm{~W}$ posynodalnej adhortacji apostolskiej Jan Paweł II stwierdził: „Nadszedł czas, by mówić odważnie o życiu kapłańskim jako o bezcennej wartości, wspaniałej i uprzywilejowanej formie życia chrześcijańskiego. Wychowawcy, a szczególnie duchowni, powinni bez lęku przedstawiać w sposób jasny i zdecydowany powołanie do kapłaństwa jako realną możliwość dla tych młodych, którzy posiadają niezbędne dary i przymioty". ${ }^{2} \mathrm{~W}$ tym samym dokumencie papież pisał: „Kościół uważa formację przyszłych kapłanów - zarówno diecezjalnych jak i zakonnych - i ich ustawiczną troskę, przez całe życie, o osobiste uświęcenie w posłudze, a także troskę o ciągłą odnowę duszpasterskiego zaanagażowania za jedno

1 Por. B e n e d y k t XVI, List do Seminarzystów, 18 X 2010, L'Osservatore Romano, wyd. pol. 11/2010, s. 3-8; B. P it a u d, La formation des futurs prêtres, un ministère spécifique au coeur de la vie de l'Eglise, Seminarium 2/1994, s. 351-367; M. G a h u n g h u, V. G a m b i n o, Formare i presbiteri. Principi e linee di metodologia pedagogica, Roma 2003, s. 23; A. F a v a l e, Vocazione comune e vocazioni specifiche. Aspetti biblici, teologici e psico-pedagogico-pastorali, Roma 1981, s. 322-330; R. S e l e j d a k, Formacja ludzka i intelektualna przyszłych kapłanów, Studia Theologica Varsaviensia UKSW 2/2013, s. 125.

2 J a n P a w eł II, Adhortacja apostolska posynodalna o formacji kapłanów we współczesnym świecie „Pastores dabo vobis”, 25 III 1992, Watykan 1992, nr 39 (dalej: PDV). 
z najdelikatniejszych i najważniejszych zadań, od których zależy przyszłość ewangelizacji ludzkości". ${ }^{3}$

Benedykt XVI z kolei zauważył, że w kontekście czynnej sekularyzacji, która stara się usunąć Boga z życia publicznego, aby człowieka uczynić niewolnikiem, również kapłaństwo i kapłan są traktowani jak „element obcy". ${ }^{4}$ Często też kapłani są znieważani i prześladowani, nawet nieraz zmuszani do złożenia świadectwa krwi. W takiej sytuacji wielu z nich nie radzi sobie, przeżywa różnego rodzaju kryzysy, załamuje się, czego konsekwencją są coraz częstsze odejścia od kapłaństwa. ${ }^{5}$

Doświadczenie uczy, że właściwa formacja przyszłych kapłanów ma ogromne znaczenie nie tylko dla owocnej posługi duszpasterskiej, ale również dla przezwyciężania różnorodnych trudności i kryzysów życiowych, co przypomniał papież Franciszek 3 października 2014 r. podczas Zgromadzenia Plenarnego Kongreacji ds. Duchowieństwa: „Trzeba troszczyć się i dbać o wzrost powołań, aby mogły przynieść dojrzałe owoce. Są one «nieoszlifowanym diamentem», nad którym należy pracować starannie, z poszanowaniem sumienia osób i z cierpliwością, aby zajaśniały pośród Ludu Bożego". ${ }^{6}$

Najnowszy dokument watykańskiej Kongregacji ds. Duchowieństwa, noszący tytuł Dar powołania do kapłaństwa. Ratio fundamentalis institutionis sacerdotalis, może stanowić ważne narzędzie dla wszystkich odpowiedzialnych za solidną formację początkową i permanentną kapłanów. ${ }^{7}$

3 Tamże, $\mathrm{nr} 2$.

4 Por. B e n e d y k t XVI, Przemówienie do uczestników Sympozjum Teologicznego zorganizowanego przez Kongregację ds. Duchowieństwa, 12 III 2010, L'Osservatore Romano, wyd. pol. 5/2010, s. 35-36.

5 Por. t e n ż e, List na rozpoczęcie Roku Kapłańskiego z okazji 150. rocznicy „,dies natalis” świętego Proboszcza z Ars, 16 VI 2009, L’Osservatore Romano, wyd. pol. 7-8/2009, s. 3.

${ }^{6}$ F r a n c is z e k, Przemówienie na Zgromadzeniu Plenarnym Kongregacji ds. Duchowieństwa, 3 X 2014, L'Osservatore Romano 4 X 2014, s. 8.

7 Por. Kongrega cja d s. D u chow i én stwa, Dar powołania do kapłaństwa. Ratio fundamentalis institutionis sacerdotalis, 8 XII 2016, L'Osservatore Romano, Supplemento 8 XII 2016 (dalej: RFIS). 


\section{Konieczność nowego Ratio fundamentalis institutionis sacerdotalis}

19 marca 1985 r. Kongregacja Edukacji Katolickiej, wówczas kompetentna w kwestiach dotyczących formacji kapłańskiej, dokonała poprawek w Ratio fundamentalis institutionis sacerdotalis, promulgowanym 6 stycznia 1970 r., uzupełniając przede wszystkim aparat krytyczny przypisów, w świetle promulgowanego 25 stycznia $1983 \mathrm{r}$. Kodeksu Prawa Kanonicznego.

Od tego momentu upłynęło ponad 30 lat. W tym okresie, przede wszystkim na skutek szybkich przemian, których nieustannie przedmiotem jest świat, zmieniły się konteksty historyczne, społeczno-kulturowe i kościelne w których kapłan jest powołany do realizacji misji Chrystusa i Kościoła. To z kolei spowodowało znaczące zmiany dotyczące obrazu kapłana, potrzeb duchowych Ludu Bożego, wyzwań nowej ewangelizacji, języka komunikacji itd.

Ponadto do formacji przyszłych prezbiterów zostało wniesionych wiele nowych elementów, zarówno strony Kościoła powszechnego, jak i przez poszczególne Kościoły partykularne.

Przede wszystkim, należy przypomnieć dokumenty papieży, którzy w tym czasie przewodzili Kościołowi: św. Jana Pawła II, któremu zawdzięczamy Adhortację apostolską Pastores dabo vobis, Benedykta XVI, autora Listu apostolskiego w formie motu proprio Ministrorum institutio oraz przemówienia i homilie Franciszka.

Nie brakowało też w tych latach dokumentów dotyczących poszczególnych aspektów formacji przyszłych duchownych, wydanych przez dykasterie Kurii Rzymskiej: Kongregację Edukacji Katolickiej, Kongregację ds. Kultu Bożego i Dyscypliny Sakramentów, Kongregację ds. Duchowieństwa, a także różnych Rationes krajowych, opracowanych przez Konferencje Episkopatów, z których wiele było konsultowanych w trakcie trwających prawie trzy lata prac nad obecnym Ratio.

W takiej sytuacji wydawało się, że formacja kapłanów powinna być ponownie odpowiednio wypromowana, odnowiona i dowartościowana. Jednym ze środków do osiągnięcia tego celu stało się 
opracowanie i promulgowanie przez Kongregację ds. Duchowieństwa nowego Ratio fundamentalis institutionis sacerdotalis.

\section{Prace przygotowawcze nad dokumentem i jego struktura}

Pierwszy projekt obecnego Ratio fundamentalis, opracowany przez Kongregację ds. Duchowieństwa już wiosną 2014 r., został przesłany do członków tej dykasterii i niektórych ekspertów, mając na względzie Zgromadzenie Plenarne, które odbyło się 1-3 października 2014 r. Podczas tego zgromadzenia tekst był komentowany i dyskutowany przez kardynałów i biskupów - członków kongregacji, a także zaproszonych ekspertów, którzy przedstawili propozycje i sugestie do dalszych prac.

Materiał ten posłużył do zredagowania tekstu poszerzonego, wzbogaconego sugestiami niektórych dykasterii Kurii Rzymskiej, zainteresowanych tym tematem ze względu na kompetencje (Kongregacja ds. Ewangelizacji Narodów, Kongregacja ds. Instytutów Życia Konsekrowanego i Stowarzyszeń Życia Apostolskiego oraz Kongregacja dla Kościołów Wschodnich) lub z racji zebranego wcześniej doświadczenia (Kongregacja Edukacji Katolickiej).

W ciągu 2015 r. tekst został przesłany do licznych Konferencji Episkopatów i nuncjatur apostolskich, w celu jego zaopiniowania. Ponadto chodziło o poszerzenie zakresu konsultacji i refleksji o te kraje, w których Ratio fundamentalis będzie zastosowane.

W dniach 19-20 listopada 2015 r. Kongregacja ds. Duchowieństwa zorganizowała Międzynarodowe Sympozjum poświęcone 50. rocznicy promulgacji dokumentów soborowych Optatam totius i Presbyterorum ordinis, podczas którego kardynałowie, biskupi, profesorowie, formatorzy i eksperci mogli zaoferować swój cenny wkład w refleksję na temat formacji kandydatów do kapłaństwa.

Kongregacja ds. Duchowieństwa, po uważnym rozważeniu propozycji otrzymanych w tej materii, zredagowała projekt dokumentu, który został najpierw przeanalizowany przez konsulatorów, a następnie przedstawiony niektórym dykasteriom Kurii Rzymskiej (Sekretariatowi Stanu, Kongregacji Nauki Wiary, Kongregacji ds. Kultu 
Bożego i Dyscypliny Sakramentów, Kongregacji ds. Biskupów, Kongregacji ds. Ewangelizacji Narodów, Kongregacji ds. Instytutów Życia Konsekrowanego i Stowarzyszeń Życia Apostolskiego, Kongregacji Edukacji Katolickiej, Kongregacji Spraw Kanonizacyjnych, Kongregacji dla Kościołów Wschodnich, Papieskiej Radzie ds. Tekstów Prawnych), w duchu współodpowiedzialności i współpracy, wspomnianym w art. 17 konstytucji Pastor Bonus.

Po zakończeniu tej konsultacji i w świetle otrzymanych sugestii została opracowana ostateczna wersja tekstu, który został przedłożony Ojcu Świętemu Franciszkowi w celu jego zatwierdzenia, zgodnie z art. 18 konstytucji Pastor Bonus.

Dokument został promulgowany przez wspomnianą dykasterię 8 grudnia 2016 r. w Uroczystość Niepokalanego Poczęcia Najświętszej Maryi Panny. Został on przetłumaczony na język angielski, hiszpański, portugalski, francuski, niemiecki i polski.

Ratio fundamentalis institutionis sacerdotalis obejmuje Wprowadzenie, osiem rozdziałów i Zakończenie. Poszczególne rozdziały noszą tytuły: Normy generalne; Powołania kapłańskie; Podstawy formacji; Formacja poczatkowa i permanentna; Wymiary formacji; Odpowiedzialni za formację; Organizacja studiów; Kryteria i normy.

\section{Zakres zastosowania dokumentu}

Obecne Ratio fundamentalis institutionis sacerdotalis ${ }^{8}$ ma być zastosowane w całości w krajach, które wchodzą w zakres kompetencji Kongregacji ds. Duchowieństwa. Uwzględniając natomiast Dekret soborowy Ad gentes, 16 i art. 88 § 2 Konstytucji apostolskiej Pastor Bonus, ma być ono zastosowane częściowo na terytoriach,

8 Dokument jest ogólnym dekretem wykonawczym, który na mocy kan. 31, §1 Kodeksu Prawa Kanonicznego, i zgodnie z przepisami tegoż Kodeksu dotyczącymi formacji, zastępuje Ratio fundamentalis institutionis sacerdotalis z 6 I 1970 r., uaktualnione przez nową edycję z 19 III 1985 r.; por. S o b ó r W a t y k a ń s k i II, „Optatam totius". Dekret o formacji kapłańskiej, 28.X.1968, w: Sobór Watykański II, Konstytucje, Dekrety, Deklaracje, Poznań 2002, nr 1 (dalej: KK). 
które należą do kompetencji Kongregacji ds. Ewangelizacji Narodów, ponieważ ta dykasteria ma zadanie „formacji duchowieństwa diecezjalnego", według własnych wytycznych i norm. Jednak obecne Ratio jest normatywne w odniesieniu do Ogólnego planu studiów na terytoriach podległych wspomnianej kongregacji. Ponadto, do norm Ratio fundamentalis powinny być dostosowane, po dokonaniu niezbędnych zmian, również Ratio instytutów życia konsekrowanego i stowarzyszeń życia apostolskiego, ${ }^{9}$ zależnych od Kongregacji ds. Instytutów Życia Konsekrowanego i Stowarzyszeń Życia Apostolskiego, a także Papieskiej Komisji Ecclesia Dei, w odniesieniu do tych „członków, którzy przygotowują się do przyjęcia święceń”, ${ }^{10}$ oraz Ratio stowarzyszeń kleryckich, którym zostało przyznane prawo inkardynacji duchownych, Prałatur personalnych, Ordynariatów polowych i Ordynariatów personalnych. ${ }^{11}$ Dlatego, w przypadku, gdy mówi się o kompetencjach ordynariusza, dotyczy to również przełożonych Wyższych Kleryckich Instytutów Życia Konsekrowanego i Stowarzyszeń Życia Apostolskiego na prawie papieskim, chyba że z kontekstu wynika, że chodzi tylko o biskupa diecezjalnego.

Zgodnie z art. 56 i 58, § 2 Konstytucji Pastor Bonus, obecne Ratio fundamentalis nie stosuje się do Katolickich Kościołów Wschodnich, podlegających kompetencji Kongregacji ds. Kościołów Wschodnich, które w tej materii mają przygotować swoje normy, biorąc pod uwagę własne dziedzictwo liturgiczne, teologiczne, duchowe i dyscyplinarne.

Należy ponadto sprecyzować, że nowe Ratio fundamentalis ma być zastosowane w całości w domach formacyjnych ruchów i nowych wspólnot kościelnych razem z Ratio krajowym, opracowanym przez Konferencję Episkopatu danego kraju, gdzie znajduje się dany instytut podlegający władzy biskupa diecezjalnego. To, co się odnosi

9 Por. J a n P awe 1 II, Konstytucja apostolska „Pastor Bonus”, 28 VI 1988, Watykan 1988, art. 88, § 2, art 108, § 2.

10 Kodeks Prawa Kanonicznego, Poznań 1984, kan 659, § 3 (dalej: KPK).

1 Por. B e n e d y k t XVI, Konstytucja apostolska ,Anglicanorum coetibus”, 4 XI 2009, Watykan 2009. 
do studiów akademickich filozofii i teologii, uznanych za takie na podstawie prawa kanonicznego, kościelnego i/lub cywilnego, jak również do fakultetów kościelnych, należy do kompetencji Kongregacji Edukacji Katolickiej, ${ }^{12}$ która ponadto ma się zatroszczyć o porozumienia z kompetentnymi władzami cywilnymi.

\section{Ratio fundamentalis institutionis sacerdotalis a Ratio krajowe}

Obecne Ratio fundamentalis institutionis sacerdotalis stanowi bazę, na podstawie której każda Konferencja Episkopatu jest zobowiązana do opracowania własnego Ratio krajowego, które zgodnie z nr 1 Dekretu soborowego Optatam totius i z kan. 242, § 1 Kodeksu Prawa Kanonicznego, musi zostać zatwierdzone przez Kongregację ds. Duchowieństwa po odpowiednich konsultacjach z Kongregacją Edukacji Katolickiej w ramach przynależnych jej kompetencji. Celem tego jest zagwarantowanie niezbędnej harmonii oraz skoordynowanie porządku studiów i ich zgodności z porządkiem studiów różnych krajów.

W przypadku pojawienia się w przyszłości nowych i nieoczekiwanych sytuacji, a w związku z tym konieczności wprowadzenia pewnych zmian we wcześniej zatwierdzonym Ratio krajowym, będzie można poprawić tekst, prosząc Kongregację ds. Duchowieństwa o jego ponowne zatwierdzenie. Rewizje tekstu i należne zatwierdzenia mogą i powinny być co jakiś czas przeprowadzane i wymagane, o ile Konferencji Episkopatu wyda się to konieczne, albo gdy dla słusznej przyczyny Kongregacja ds. Duchowieństwa uzna to za stosowne. ${ }^{13}$

12 Poszczególne kompetencje dwóch dykasterii zostały określone przez Benedykta XVI w Liście apostolskim Ministrorum institutio z 16 I 2013 r., w art. 6: „Do kompetencji Kongregacji Edukacji Katolickiej należy porządek studiów akademickich filozofii i teologii, po uprzedniej konsultacji Kongregacji ds. Duchowieństwa, w ramach odnośnych kompetencji”.

13 Por. KPK, kan. 242, § 1. 
Prawo i obowiązek opracowania Ratio nationalis institutionis sacerdotalis, jak również zatwierdzenie szczególnych doświadczeń na terytorium danej Konferencji Episkopatu bądź regionu, o ile wydawałoby się to stosowne i pożyteczne, należą do kompetencji Konferencji Episkopatu, a nie do poszczególnych biskupów. ${ }^{14}$

Normy takiego Ratio mają być przestrzegane we wszystkich seminariach diecezjalnych i międzydiecezjalnych tego kraju, ${ }^{15} \mathrm{a}$ ich szczegółowe zastosowanie winno znaleźć się w Statucie, Regulaminie i we własnych Projektach formacyjnych każdej z tych instytucji. ${ }^{16}$

\section{Tożsamość kapłańska jako podstawa i cel formacji przyszłych kapłanów}

W czasach współczesnych są jeszcze rozpowszechniane tu i ówdzie niejasne czy też całkowicie błędne koncepcje tożsamości kapłańskiej. Na przykład propaguje się: koncepcję kapłaństwa jedynie funkcjonalnego; kapłaństwa czysto horyzontalnego; ideę kapłana rozumianego jako delegata wspólnoty wiernych w celu zagwarantowania jej organizacji i wypełnienia jakiejś misji o charakterze czasowym; wizję indywidualistyczną kapłaństwa bez jakiegokolwiek odniesienia eklezjologicznego i nie mającego wpływu na problemy codziennego życia.

Ponadto w środowiskach kościelnych często zapomina się, że kapłaństwo wspólne wiernych różni się od kapłaństwa służebnego nie tylko stopniem, ale również istotą.

Aby wyjść naprzeciw takiej sytuacji, obecne Ratio fundamentalis wzywa wszystkich odpowiedzialnych za formację kapłańską do ukazywania seminarzystom tożsamości kapłana zgodnej z nauczaniem Urzędu Nauczycielskiego Kościoła. Muszą oni jasno ukazywać różnicę ontologiczną między kapłaństwem wspólnym wiernych a kapłaństwem służebnym, bazującym na specyficznym znamieniu wyciśniętym w sposób niezatarty na duszy wyświęconego

\footnotetext{
14 Por. tamże.

15 Por. tamie, § 2.

16 Por. tamże, kan. 243.
} 
przez sakrament święceń. ${ }^{17}$ Dokument przypomina, że prezbiterzy, w komunii z biskupami, stanowią nieodłączną część wspólnoty kościelnej, a jednocześnie są ustanowieni do bycia pasterzami oraz przewodnikami z woli Chrystusa w ciągłości z dziełem apostołów. Dlatego „kapłan pełni swój urząd nie tylko w Kościele, lecz również wobec Kościoła". ${ }^{18}$ Prezbiter, jako członek świętego Ludu Bożego, jest powołany do pielęgnowania swego misyjnego dynamizmu, sprawując z pokorą duszpasterskie zadanie wiarygodnego przewodnika, głosiciela słowa i szafarza sakramentów, ${ }^{19}$ realizując w ten sposób owocne ojcostwo duchowe. ${ }^{20}$

Dlatego, według Ratio, przyszli kapłani winni być formowani tak, by nie popadali w „klerykalizm”, ani nie ulegali pokusie opierania własnego życia na poszukiwaniu ludzkiego poparcia, co nieuchronnie osłabiłoby ich zdolność do sprawowania posługi przewodnika wspólnoty, prowadząc ich do traktowania Kościoła jak instytucji czysto ludzkiej.

Z drugiej strony, święcenia kapłańskie, które wraz z wylaniem Ducha Świętego przez nałożenie rąk przez biskupa uczyniły prezbitera przewodnikiem ludu, nie powinny prowadzić go do „ciemiężenia” swej owczarni (por. 1P 5, 3): „Każda władza powinna być bowiem pełniona w duchu służby, jako «amoris officium» $\mathrm{i}$ bezinteresowne poświęcenie dla dobra owczarni”, ${ }^{21}$

\section{Formacja początkowa i permanentna}

Ratio fundamentalis institutionis sacerdotalis ukazuje formację kapłańską jako jedyną i ciągłą drogę bycia uczniem i misjonarzem

\footnotetext{
17 Por. RFIS, nr 30-32.

18 Por. tamże, nr 32; por. także PDV, nr 16.

19 Por. K o ng re g a c j a d s. D u c how i eń s t w a, Kapłan głosiciel słowa, szafarz sakramentów i przewodnik wspólnoty w drodze do Trzeciego Tysiaclecia chrześcijaństwa, 19 III 1999, Rzym 1999.

20 Por. RFIS, nr 33.

${ }_{21}$ Por. tamże, nr 33-34; por. F r a n c i s z e k, Przemówienie podczas Audiencji generalnej, 26 III 2014, L'Osservatore Romano 27 III 2014, s. 8.
} 
Chrystusa. Może być ona podzielona na dwa główne okresy: formację początkową, obejmującą czas poprzedzający święcenia kapłańskie i formację permanentną w życiu kapłańskim. ${ }^{22}$

Formacja początkowa i jej etapy

Formacja początkowa dzieli się na cztery duże etapy: etap propedeutyczny, etap studiów filozoficznych albo bycia uczniem, etap studiów teologicznych albo upodabniania się do Chrystusa i etap pastoralny albo syntezy powołaniowej.

\section{Etap propedeutyczny}

Etap propedeutyczny jest przedstawiony przez Ratio jako konieczny i obowiązkowy. Winien on trwać nie krócej niż rok i nie dłużej niż dwa lata. Jego głównym celem jest pomoc kandydatowi do kapłaństwa we właściwym rozeznaniu powołania, położenie solidnych podwalin pod jego życie duchowe, wspieranie go w lepszym poznaniu siebie w celu osobistego wzrostu oraz wprowadzenie do następnych etapów formacji początkowej. Dlatego na tym etapie będzie konieczne przede wszystkim włączenie seminarzysty w modlitwę, życie sakramentalne, liturgię godzin, zażyłą znajomość słowa Bożego, milczenie i lekturę duchową. Poza tym ma to być odpowiedni czas na pierwsze i syntetyczne poznanie chrześcijańskiej doktryny przez studium Katechizmu Kościoła Katolickiego oraz na rozwinięcie dynamiki daru z siebie w doświadczeniu parafialnym i charytatywnym. Wreszcie etap propedeutyczny winien posłużyć do ewentualnego uzupełnienia formacji kulturalnej kandydata. Studia na tym etapie powinny być wyraźnie oddzielone od filozoficznych.

Ważne jest, aby w propozycji formacyjnej podkreślić aspekt komunii z własnym biskupem, z prezbiterium i z całym Kościołem

22 Por. RFIS, nr 54-55; por. F r a n c i s z e k, List do uczestników Nadzwyczajnego Zgromadzenia Generalnego Konferencji Episkopatu Włoch, 8 XI 2014, L'Osservatore Romano 12 XI 2014, s. 7. 
partykularnym, również ze względu na fakt, że wiele powołań, zwłaszcza w czasach współczesnych, pochodzi z różnych grup oraz wspólnot i jest konieczne, by rozwijały one głębsze więzi z rzeczywistością diecezjalną. ${ }^{23}$

Następnie dokument zachęca, aby etap propedeutyczny był przeżywany w odrębnej wspólnocie od wyższego seminarium duchownego, a gdzie jest to możliwe, miał również konkretne miejsce na swoją siedzibę oraz własnych formatorów. ${ }^{24}$

\section{Etap studiów filozoficznych (albo bycia uczniem)}

Etap bycia uczniem Chrystusa to czas zakorzeniania seminarzysty w pójściu za Chrystusem, w słuchaniu Jego słowa, w zachowywaniu go w sercu i wprowadzaniu w życie. Ten specyficzny czas charakteryzuje się formacją ucznia Jezusa, którego przeznaczeniem jest bycie pasterzem, ze zwróceniem specjalnej uwagi na wymiar ludzki, w harmonii ze wzrostem duchowym. W ten sposób wspiera się seminarzystę w dojrzewaniu do ostatecznej decyzji pójścia za Panem w kapłaństwie służebnym, w przyjmowaniu rad ewangelicznych, według właściwych sposobów dla tego etapu.

Na tym etapie seminarzyści winni być przyzwyczajani do kształtowania własnego charakteru, do wzrastania w sile ducha i w ogóle do uczenia się cnót ludzkich, takich jak: szczerość ducha, nieustanne zabieganie o sprawiedliwość, dotrzymywanie przyrzeczeń, życzliwość w postępowaniu, w rozmowie zaś skromność, połączona z miłością, które uczynią ich żywym odzwierciedleniem człowieczeństwa Chrystusa i pomostem łączącym ludzi z Bogiem. Kandydaci do kapłaństwa powinni być też wychowywani do panowania nad sobą, przezwyciężania różnych form indywidualizmu, a także do składania z siebie szczerego daru, który otwiera na ofiarne poświęcenie się innym. ${ }^{25}$

23 Por. RFIS, nr 59-60; por. także K o ng re g a c ja E duk a cji K a to li ck i ej, Dokument informacyjny „Okres propedeutyczny”, 10 V 1998, Rzym 1998, III, 1-5.

24 Por. RFIS, nr 60.

25 Por. tamże, nr 63; por. także KK, nr 11. 
Na tym etapie formacji wychowawcy, a zwłaszcza kierownik duchowy, winni zaproponować program pedagogiczny, który wspierałby seminarzystów w dynamice ich duchowego wzrostu, pomagając im uświadomić sobie własne ubóstwo, a jednocześnie potrzebę Bożej łaski oraz braterskiego upomnienia.

Etap ten, który nie powinien być krótszy niż dwa lata, winien obejmować wystarczająco dużo czasu, aby osiągnąć właściwe mu cele, a jednocześnie zdobyć niezbędną wiedzę z zakresu filozofii i nauk humanistycznych. Jest konieczne, aby ten etap był należycie doceniony i rozumiany w świetle swoich specyficznych celów, a nie był postrzegany jako „obowiązkowe przejście” w celu przystąpienia do studiów teologicznych. ${ }^{26}$

\section{Etap studiów teologicznych (albo upodabniania się do Chrystusa)}

Etap studiów teologicznych, albo upodabniania się do Chrystusa, w sposób szczególny jest skierowany na formację duchową prezbitera, gdzie stopniowe formowanie się na wzór Chrystusa staje się doświadczeniem, które pobudza w życiu ucznia uczucia i postawy właściwe dla Syna Bożego. Jednocześnie wprowadza w poznanie kapłańskiego życia, ożywianego pragnieniem i zdolnością do ofiarowania siebie w duszpasterskiej trosce o Lud Boży. Ten etap pozwala na stopniowe zakorzenianie się kandydata do kapłaństwa w fizjonomii Dobrego Pasterza, który zna swoje owce, daje za nie życie oraz idzie na poszukiwanie owiec, które są poza owczarnią (por. J 10, 17). ${ }^{27}$

Treści zawarte w tym etapie są wymagające i bardzo zobowiązujące. Wymaga się bowiem od seminarzystów ciągłej odpowiedzialności, aby żyli cnotami kardynalnymi, teologalnymi i radami ewangelicznymi oraz ulegali działaniu Boga przez dary Ducha Świętego, zgodnie z czysto kapłańską i misyjną perspektywą. Jest także konieczne, by stopniowo odczytywali osobistą historię, według

26 Por. RFIS, nr 65-66.

27 Por. tamże, nr 69; por. także K ong re g a c ja d s. D u chow i eń s twa, Dyrektorium o postudze i życiu prezbiterów, 11 II 2013, Rzym 2013, nr 8 (dalej: DPŻP). 
spójnego profilu pasterskiej miłości, która ożywia, formuje i motywuje życie prezbitera. ${ }^{28}$

W tym czasie szczególne zaangażowanie seminarzystów w upodabnianie się do Chrystusa Sługi i Pasterza zbiega się z ich studium teologii. W praktyce formatorzy powinni zadbać o zapewnienie kandydatom do kapłaństwa owocnej harmonii między dojrzewaniem ludzkim a duchowym oraz między życiem modlitwy a poznawaniem teologii.

W trakcie tego etapu, w zależności od dojrzałości każdego kandydata i w ramach możliwości formacyjnych, należy udzielić seminarzystom posług lektoratu i akolitatu, by mogli je sprawować przez odpowiedni okres i przygotować się lepiej do przyszłej służby Słowa i Ołtarza. Lektorat stawia seminarzystę przed „wyzwaniem”, aby dać się przemieniać słowu Bożemu, które ma być przedmiotem jego modlitwy i studium. Udzielenie posługi akolitatu włącza w głębsze uczestnictwo w misterium Chrystusa, który daje się i jest obecny w Eucharystii, w zgromadzeniu i w bliźnim. ${ }^{29}$

Na końcu wspomnianego etapu, seminarzysta - o ile biskup, po wysłuchaniu formatorów, uzna go za zdatnego - winien poprosić i otrzymać święcenia diakonatu, przez które włączony do stanu duchownego, wraz ze związanymi z nimi obowiązkami i prawami, zostaje inkardynowany do jakiegoś Kościoła partykularnego albo do prałatury personalnej, albo do jakiegoś instytutu życia konsekrowanego lub stowarzyszenia, albo do jakiegoś zrzeszenia lub ordynariatu, które posiada tę zdolność. ${ }^{30}$

\section{Etap pastoralny (albo syntezy powołaniowej)}

Etap pastoralny (albo syntezy powołaniowej) obejmuje okres między pobytem w seminarium, a święceniami diakonatu i kapłaństwa.

28 Por. RFIS, nr 69; por. także PDV, nr 23 i 27.

29 Por. RFIS, nr 70, 72; por. P a w e 1 VI, List apostolski „Ministeria quaedam”, 15 VIII 1972, Watykan 1972, V-VI.

30 Por. RFIS, nr 73; por. także KPK, kan. 265. 
Cel tego etapu jest dwojaki: z jednej strony chodzi o to, by być włączonym w życie duszpasterskie, przy stopniowym podejmowaniu odpowiedzialności w duchu służby; z drugiej zaś strony, o podjęcie starań w celu odpowiedniego przygotowania z myślą o prezbiteracie, otrzymując szczególne towarzyszenie formatorów. Na tym etapie, po otrzymaniu święceń diakonatu, kandydat jest zaproszony do zadeklarowania w sposób wolny, świadomy i ostateczny swej woli bycia kapłanem. ${ }^{31}$

Ten etap odbywa się zazwyczaj poza budynkiem seminarium, przynajmniej przez znaczną część czasu i z reguły przeżywa się go w posłudze na rzecz jakiejś wspólnoty. Czas jego trwania jest zmienny i zależy od rzeczywistej dojrzałości i od zdatności kandydata. Należy jednak przestrzegać przynajmniej ustalonego kanonicznie czasu między przyjęciem diakonatu i prezbiteratu. ${ }^{32}$

$\mathrm{Na}$ zakończenie formacyjnego cyklu w seminarium formatorzy winni pomóc kandydatowi, by przyjął w posłuszeństwie decyzję wydaną w stosunku do niego przez biskupa. ${ }^{33}$

\section{Formacja permanentna}

Według Ratio fundamentalis institutionis sacerdotalis określenie „formacja permanentna" przypomina ideę, że jedyne doświadczenie bycia uczniem tych, którzy są powołani do kapłaństwa, nigdy się nie kończy. Kapłan nie tylko „uczy się poznawać Chrystusa”, ale pod wpływem działania Ducha Świętego, znajduje się wewnątrz procesu stopniowego i ciągłego upodabniania się do Niego w byciu i w działaniu, które stanowi stałe wyzwanie w wewnętrznym rozwoju osoby. ${ }^{34}$

31 Por. RFIS, nr 74.

32 Por. tamże, nr 76; por. także KPK, kan. 1031, § 1, kan. 1032, § 2.

33 Por. RFIS, nr 77; por. B e n e d y k t XVI, Adhortacja apostolska posynodalna „Sacramentum caritatis”, 22 II 2007, Watykan 2007, nr 25.

34 Por. RFIS, nr 80; por. Fr a n c is z e k, Przemówienie do Zgromadzenia Plenarnego Kongregacji ds. Duchowieństwa, 3 X 2014, L'Osservatore Romano 4 X 2014, s. 8. 
Formacja permanentna ma na celu zapewnienie wierności posłudze kapłańskiej, na drodze ciągłego nawracania się, aby ożywiać dar otrzymany podczas święceń. Ta droga jest naturalną kontynuacją procesu kształtowania tożsamości kapłańskiej, zapoczątkowanego w seminarium i dopełnionego w święceniach kapłańskich, z myślą o posłudze duszpasterskiej, która sprawia, że owa tożsamość dojrzewa wraz z upływem czasu. ${ }^{35}$

Dokument Kongregacji ds. Duchowieństwa podkreśla, że formacja permanentna powinna być konkretna, to znaczy włączona w rzeczywistość kapłańską, tak by wszyscy kapłani mogli ją realnie podjąć, mając na względzie fakt, że pierwszym i głównym odpowiedzialnym za własną formację permanentną jest sam prezbiter. Wskazane jest, aby była ona promowana w każdej diecezji przez kapłana lub grupę kapłanów, uformowanych w szczególny sposób i oficjalnie wyznaczonych do tego, by wspierali posługę na jej rzecz, biorąc pod uwagę wiek i szczególne okoliczności każdego współbrata. ${ }^{36}$

Do inicjatyw, które powinny być zaproponowane w czasie formacji permanentnej, Ratio zalicza m.in.: organizowanie braterskich spotkań kapłanów poświęconych modlitwie, wspólnemu czytaniu słowa Bożego, pogłębianiu jakiegoś tematu teologicznego bądź duszpasterskiego, dzieleniu się doświadczeniem nabytym w pracy duszpasterskiej, albo po prostu spędzeniu wspólnie czasu; kierownictwo duchowe i spowiedź; rekolekcje; wspólnotę stołu; życie wspólnotowe i stowarzyszenia kapłańskie. ${ }^{37}$

\section{Integralna formacja kapłańska i jej wymiary}

W adhortacji apostolskiej Ecclesia in Europa Jan Paweł II pisał: „Kapłani na mocy swej posługi są powołani, by (...) celebrować Ewangelię nadziei, głosić ją i jej służyć. (...) Winni oni upodobnić całe swoje życie i swoje działanie do Jezusa. (...) Przez sprawowanie

\footnotetext{
35 Por. RFIS, nr 81; por. także PDV, nr 70-71.

36 Por. RFIS, nr 82; por. także DPŻP, nr 108.

37 Por. RFIS, nr 88.
} 
swej posługi mają oni przedłużać obecność Chrystusa, jedynego i najwyższego Pasterza; a przez naśladowanie Jego stylu życia ukazywać Go w sposób przejrzysty powierzonej owczarni. Żyjąc w świecie, ale nie będąc ze świata (por. J 17, 15-16), (...) są wezwani, by być znakiem sprzeciwu i nadziei dla społeczeństwa chorego na horyzontalizm i potrzebującego otwarcia na Transcendencję". ${ }^{38}$

Nie ulega wątpliwości, że wierne i ofiarne wypełnienie takiego zadania będzie możliwe jedynie wtedy, gdy przyszłym kapłanom zostanie zagwarantowana w seminarium solidna formacja integralna.

Formację tego typu ukazał Jan Paweł II już w 1992 r., gdy w adhortacji Pastores dabo vobis podkreślał, że winna obejmować ona wymiar ludzki, duchowy, intelektualny i duszpasterski, wzajemnie ze sobą połączone i uzupełniające się. ${ }^{39}$ Bardzo podobną formację zaleca również obecne Ratio fundamentalis institutionis sacerdotalis. ${ }^{40}$

\section{Wymiar ludzki}

Formacja ludzka stanowi fundament całej formacji kapłańskiej. ${ }^{41}$ Kapłan, który jest powołany, by być żywym obrazem Jezusa Chrystusa Głowy i Pasterza Kościoła, „powinien starać się odtworzyć w sobie, w miarę możliwości, ludzką doskonałość jaśniejącą w Synu Bożym,

38 J a n P a w e $\nmid$ II, Adhortacja apostolska „Ecclesia in Europa”, 28 VI 2003, Watykan 2003, nr 34.

39 Por. PDV, nr 43-59; por. F r a n c is z e k, Przemówienie do biskupów polskich przybylych do Watykanu z wizyta ,Ad limina Apostolorum”, 7 II 2014, L'Osservatore Romano, wyd. pol. 2/2014, s. 29; t e n ż e, Przemówienie podczas spotkania w Auli Pawta VI z seminarzystami, nowicjuszami, nowicjuszkami i młodzieża będąca na drodze powołania, L'Osservatore Romano, wyd. pol. 8-9/2013, s. 44; t e n ż e, Dialogo con gli studenti dei Pontifici Collegi e Convitti di Roma nell'Aula Paolo VI, L'Osservatore Romano 14 V 2014, s. 4.

40 Por. RFIS, nr 89-124.

41 Por. PDV, nr 43; RFIS, nr 94. 
który stał się człowiekiem, ujawniającą się szczególnie wyraźnie w Jego postawie wobec innych, tak jak ukazują to Ewangeliści". ${ }^{42}$

Jezus Chrystus winien więc stanowić dla każdego seminarzysty wzór oraz źródło doskonałości ludzkiej i chrześcijańskiej. To, co jako przyszły kapłan będzie mówił i czynił, ma być tym wszystkim, czego nauczał Jezus Chrystus i tym wszystkim, co czynił On ludziom. Kandydat do kapłaństwa nie może zapomnieć, że ma stać się żywym sakramentem obecności kapłańskiej Chrystusa w Kościele.

W tym kontekście Ratio podkreśla, że formacja ludzka winna promować wzrost integralny osoby seminarzysty we wszystkich jej wymiarach. $Z$ punktu widzenia fizycznego winna brać pod uwage jego zdrowie, odżywianie, aktywność motoryczną i odpoczynek. W wymiarze psychologicznym powinna zajmować się ukonstytuowaniem stabilnej osobowości seminarzysty, odznaczającej się dojrzałością uczuciową, panowaniem nad sobą i dobrze zintegrowaną seksualnością. W wymiarze moralnym winna wymagać, aby jednostka stopniowo nabywała dobrze ukształtowane sumienie moralne, a więc stawała się osobą odpowiedzialną, zdolną do podejmowania słusznych decyzji, mającą prawidłowy osąd oraz zdolność obiektywnej percepcji osób i wydarzeń. Taka percepcja powinna doprowadzić seminarzystę do zrównoważonej samooceny, która pozwoliłaby uświadomić mu posiadane przymioty, tak by nauczył się korzystać z nich w posłudze Ludowi Bożemu.

W formacji ludzkiej kandydata do kapłaństwa należy zadbać też o nabycie przez niego zdolności do utrzymywania dojrzałych relacji z mężczyznami i kobietami, każdego wieku i pozycji społecznej, aby w ten sposób mógł przyczynić się do budowania wspólnoty, w której żyje.

Aby takie działanie wychowawcze mogło być owocne, ważne jest, by każdy seminarzysta świadomie otworzył się na formatorów w tym, co dotyczy jego historii, sposobu przeżycia dzieciństwa i wieku młodzieńczego, wpływu, jaki wywarli na niego rodzina i krewni, zdolności lub jej braku do nawiązywania zrównoważonych

42 PDV, nr 43. 
relacji międzyosobowych, jak również umiejętności pozytywnego przeżywania chwil samotności. Informacje te mają duże znaczenie dla wyboru przez formatorów właściwych środków pedagogicznych, przy ocenie procesu formacyjnego, oraz lepszego zrozumienia ewentualnych momentów regresu czy trudności seminarzysty. ${ }^{43}$

\section{Wymiar duchowy}

Formacja ludzka, zakorzeniona w antropologii przyjmującej pełną prawdę o człowieku, otwiera się i znajduje swe dopełnienie w formacji duchowej, która jest ukierunkowana na podtrzymywanie i ożywianie więzi seminarzysty z Bogiem i braćmi, w przyjaźni z Jezusem Dobrym Pasterzem i postawie uległości wobec Ducha Świętego. Ta intymna relacja kształtuje serce seminarzysty do miłości hojnej i ofiarnej, która stanowi początek miłości pasterskiej. ${ }^{44}$

Jest oczywiste, że kandydaci do kapłaństwa, w celu koniecznego kształtowania się na wzór Chrystusa, winni być przede wszystkim formowani do nabycia bardzo żywej wiary w Eucharystię. Uczestnictwo w codziennej celebracji Eucharystii, które znajduje swe naturalne przedłużenie w adoracji eucharystycznej, winno przenikać życie seminarzysty w taki sposób, że dojrzeje w nim stała więź z Panem. ${ }^{45}$

Według Ratio, formatorzy w formacji duchowej seminarzystów powinni nauczyć ich zażyłości ze słowem Bożym, które - zanim będzie przepowiadane - musi być przyjęte w głębi serca, zwłaszcza w kontekście nowej ewangelizacji, do której Kościół jest dziś powołany. ${ }^{46}$ Ono jest stałym punktem odniesienia dla życia ucznia Chrystusowego i upodobnienia duchowego do Chrystusa Dobrego Pasterza. Seminarzystów należy zatem stopniowo wprowadzać w poznanie słowa Bożego za pomocą metody lectio divina. Codzienne i głębokie

\footnotetext{
43 Por. RFIS, nr 94-95.

44 Por. tamie, nr 101.

45 Por. tamże, nr 104; por. także PDV, nr 48.

46 Por. RFIS, nr 103; por. także PDV, nr 47.
} 
rozmyślanie, wiernie i pilnie praktykowane, wzbogacone studium i modlitwą, będzie mogło zagwarantować im nawiązanie integralnego kontaktu zarówno ze Starym jak i Nowym Testamentem. ${ }^{47}$

W życiu duchowym przyszłych kapłanów nie może zabraknąć Liturgii Godzin, która prezentuje prawdziwą i właściwą „szkołę modlitwy”. Przyswajając sobie stopniowo modlitwę Kościoła za pośrednictwem liturgii godzin, powinni oni uczyć się smakować jej bogactwo i piękno. ${ }^{48}$

W formacji duchowej niezwykle konieczna i pilna jest także pomoc seminarzystom w częstym i regularnym przystępowaniu do spowiedzi świętej, przygotowanej przez codzienny rachunek sumienia. ${ }^{49}$ Sakrament pokuty staje się bowiem dla nich okazją do uznania z pokorą własnych słabości i grzechów, a przede wszystkim do zrozumienia i doświadczenia radości bycia kochanym i rozgrzeszonym przez Pana. Ponadto z tego sakramentu ,wypływa sens ascezy i wewnętrznej dyscypliny, duch ofiary i wyrzeczenia, zgoda na przyjęcie trudów i krzyża". ${ }^{50}$ Jest to zadanie formatorów mające wielkie znaczenie zwłaszcza w kulturze współczesnej, charakteryzującej się coraz to nowymi, a przy tym coraz bardziej wyrafinowanymi formami samousprawiedliwienia i w związku z tym narażonej na zgubną utratę poczucia grzechu, a w konsekwencji również pociechy, którą przynosi prośba o przebaczenie. ${ }^{51}$

Seminarzyści powinni mieć do dyspozycji spowiedników zwyczajnych, a także innych, przychodzących regularnie do seminarium. Zawsze jednak kandydaci do kapłaństwa powinni mieć możliwość swobodnego udania się do dowolnie wybranego spowiednika, w seminarium lub poza nim. ${ }^{52}$

47 Por. RFIS, nr 103.

48 Por. tamże, nr 105; por. także PDV, nr 26.

49 Por. RFIS, nr 106: por. także PDV, nr 48; R. S e l e j d a k, Stawać się kapłanem trzeciego tysiąclecia, Częstochowa 2001, s. 55.

50 PDV, nr 48; por. także RFIS, nr 106.

51 Por. PDV, nr 48.

52 Por. KPK, kan. 240, § 1. 
Nie ulega wątpliwości, że kandydaci do kapłaństwa nie będą mogli stać się dobrymi i skutecznymi szfarzami pokuty oraz wiarygodnymi świadkami miłosierdzia Bożego dla grzeszników, o ile wpierw sami $\mathrm{z}$ niego nie będą korzystali. ${ }^{53}$

Z sakramentem pokuty łączy się ściśle kierownictwo duchowe, które stanowi uprzywilejowane narzędzie integralnego wzrostu osoby. Obecne Ratio fundamentalis przypomina, że kierownik duchowy winien być wybrany w poczuciu pełnej wolności przez seminarzystów spośród kapłanów wyznaczonych przez biskupa. ${ }^{54}$ Wolność wyboru jest prawdziwie autentyczna tylko wtedy, gdy seminarzysta otworzy się szczerze, ufnie i ulegle. Spotkania z kierownikiem duchowym nie mogą być przypadkowe, lecz systematyczne i regularne. Jakość kierownictwa duchowego wpływa bowiem w dużej mierze na skuteczność całego procesu formacyjnego. ${ }^{55}$

W programie formacji duchowej nie może zabraknąć rekolekcji, które winny być odprawiane przez seminarzystów każdego roku, ${ }^{56}$ jako czas głębokiej weryfikacji duchowej w przedłużonym modlitewnym spotkaniu z Bogiem, przeżywanych w atmosferze skupienia i ciszy. Rekolekcje winny być kontynuowane w ciągu roku w formie okresowych dni skupienia i w codziennej modlitwie. W ten sposób, w sercu seminarzysty, kształtowanym przez działanie Ducha Świętego, stopniowo pojawi się i umocni pragnienie hojnego oddania własnego życia dla realizacji miłości pasterskiej. ${ }^{57}$

Ponadto formatorzy winni wychowywać kandydatów do kapłaństwa do praktykowania w swoim życiu rad ewangelicznych: posłuszeństwa, ubóstwa, a zwłaszcza czystości. W dzisiejszych bowiem czasach coraz więcej seminarzystów w niewłaściwy sposób rozumie celibat kapłański, ma kłopoty z podjęciem decyzji do życia w nim, a następnie do zachowywania go. Trudności te są spowodowane

\footnotetext{
53 Por. PDV, nr 26.

54 Por. RFIS, nr 107; por. także KPK, kan. 239, § 2.

55 Por. RFIS, nr 107.

56 Por. KPK, kan. 246, §5.

57 Por. RFIS, nr 108.
} 
m.in. coraz częstszymi dyskusjami podważającymi sens celibatu. Propagowane są one szczególnie przez środki społecznego przekazu. Podejmują je również niektóre publikacje teologiczne, niezgodne w tym względzie z nauczaniem Kościoła. Dodać należy także negatywne świadectwo niektórych duchownych czy też brak pomocy i zrozumienia ze strony wiernych.

W tej sytuacji Ratio fundamentalis ukazuje zagadnienie celibatu, biorąc pod uwagę jego elementy ludzkie, a zwłaszcza motywacje nadprzyrodzone. Dokument potwierdza, że Kościół łaciński uważa doskonałą czystość w celibacie, ze względu na królestwo niebieskie, za szczególnie odpowiadającą kapłaństwu. Przypomina w tym względzie dekret soborowy Presbyterorum ordinis, który nauczał, że zakorzenieni w Chrystusie Oblubieńcu i całkowicie oddani służbie Ludowi Bożemu w celibacie, prezbiterzy, „lgną łatwiej niepodzielnym sercem do Niego [Chrystusa], z większą swobodą (...) służą Bogu i ludziom (...) i w ten sposób stają się podatniejsi na przyjęcie szerszego ojcostwa w Chrystusie". ${ }^{58}$ Dlatego, według Ratio, ci, którzy przygotowują się do kapłaństwa, powinni uznać i zaakceptować celibat jako szczególny dar Boga. Aby następnie wybór celibatu był rzeczywiście wolny, konieczne jest, by seminarzyści, wsparci światłem wiary, mogli zrozumieć moc ewangeliczną tego daru i jednocześnie w sposób właściwy docenić wartość stanu małżeńskiego. Byłoby wielce nierozważne dopuścić do sakramentu święceń seminarzystę, który nie osiągnął właściwej dojrzałości uczuciowej, wiernej w czystości celibatu, przez realizację cnót ludzkich i kapłańskich, rozumianych jako otwarcie na działanie łaski, a nie jako samą wolę zachowania wstrzemięźliwości. ${ }^{59}$

W formacji duchowej winno się także zachęcać seminarzystów do pielęgnowania w sobie autentycznej i synowskiej pobożności do Maryi Dziewicy, zarówno przez wspominanie Jej w liturgii, jak też

58 Tamże, nr 110; S o b ó r W a t y k a ń s k i II, ,Presbyterorum ordinis”. Dekret o posłudze i życiu prezbiterów, 7 XII 1965, w: Sobór Watykański II, Konstytucje, Dekrety, Deklaracje, nr 16.

59 Por. RFIS, nr 110. 
w pobożności ludowej, szczególnie przez odmawianie różańca i modlitwy Anioł Pański. ${ }^{60}$

Nie można zapominać o znaczeniu szczerej pobożności do świętych, szczególnie do św. Józefa; o ukazywaniu i rozważaniu pism Ojców Kościoła oraz o praktykach pobożnościowych związanych z religijnością lub pobożnością ludową, zwłaszcza w formach zatwierdzonych przez Magisterium Kościoła. Dzięki tym ostatnim praktykom przyszli kapłani głębiej wejdą w „duchowość ludową”, którą winni właściwie oceniać, ukierunkować i przyjąć w imię miłości oraz duszpasterskiej skuteczności. ${ }^{61}$

\section{Wymiar intelektualny}

Dzisiaj kapłan wezwany jest do głoszenia Ewangelii światu często obojętnemu na wartości religijne oraz do rozwiązywania różnorodnych i złożonych problemów ludzkich. $\mathrm{Z}$ tego względu formacja intelektualna powinna być pielęgnowana $\mathrm{z}$ największą strannością i ukierunkowana na osiągnięcie przez seminarzystów solidnej kompetencji w zakresie filozoficznym i teologicznym, a także na przygotowanie kulturalne o charakterze ogólnym. ${ }^{62}$

Dlatego też, aby uniknąć fragmentaryzacji, wszystkie dyscypliny powinny być wykładane w taki sposób, by było jasno podkreślone ich wewnętrzne powiązanie ze sobą. Chodzi o proces harmonijny i integralny, ${ }^{63} \mathrm{w}$ którym wszystkie przedmioty są ważnymi „elementami składowymi” w celu ukazania tajemnicy Chrystusa i Kościoła, służącymi również do dojrzewania autentycznej chrześcijańskiej wizji człowieka i świata.

60 Por. tamże, nr 112.

61 Por. tamże, nr 112-114.

62 Por. PDV, nr 51; RFIS, nr 116; B e ne dy k t XVI, List do Seminarzystów, nr 5, s. 6; F r a n c i s z e k, Dialogo con gli studenti dei Pontifici Collegi e Convitti di Roma nell'Aula Paolo VI, s. 4.

63 Por. KPK, kan. 254, § 1. 
Aktualne Ratio fundamentalis, podobnie jak to z 1970 r., obejmuje Ordo studiorum, które czas formacji intelektualnej dzieli na studium przedmiotów propedeutycznych, studia filozoficzne, studia teologiczne, studium przedmiotów „służących bezpośrednio posłudze kapłańskiej” i studia specjalistyczne oraz zawiera wykaz dyscyplin naukowych, które powinny być studiowane we wspomnianych okresach studiów. ${ }^{64}$

\section{Studium przedmiotów propedeutycznych}

Przy programowaniu przedmiotów, które według wspomnianego Ordo studiorum winny być wykładane w okresie propedeutycznym, należy uwzględnić sytuację społeczeństwa oraz Kościoła partykularnego, gdzie dokonuje się proces edukacyjny. Seminarzystom trzeba zapewnić nabycie rozległej wiedzy z zakresu nauki wiary ${ }^{65}$ i zrozumienia elementów posługi kapłańskiej. Ponadto należy odpowiednio uzupełnić ewentualne braki w wykształceniu po ukończeniu przez nich szkoły średniej.

Niektóre przedmioty charakterystyczne dla tego okresu formacji to np.: wprowadzenie do lektury Pisma Świętego, które pozwoli na wstępne poznanie wszystkich jego części; wprowadzenie w tajemnicę Chrystusa i Kościoła, w teologię kapłaństwa i liturgię, przez studium Katechizmu Kościoła Katolickiego i ksiąg liturgicznych; wprowadzenie do dokumentów II Soboru Watykańskiego i Urzędu Nauczycielskiego Kościoła, zwłaszcza papieskiego; elementy duchowości kapłańskiej, ze szczególnym uwzględnieniem postawowych „szkół” duchowości i świętych, którzy dali świadectwo przykładnego życia kapłańskiego; elementy historii Kościoła powszechnego i lokalnego, zwłaszcza w aspektach misyjnych; hagiografia ukazująca świętych i błogosławionych własnej diecezji lub regionu; elementy kultury humanistycznej przez poznanie dzieł autorów krajowych, a także

64 Por. RFIS, nr 155-185.

${ }_{65}$ Por. Kongrega cja Edukacji Katolickiej, Dokument informacyjny „Okres propedeutyczny”, III, 1; por. także RFIS, nr 156. 
religii niechrześcijańskich kraju i regionu; elementy psychologii, które mogą pomóc seminarzyście w poznaniu samego siebie. ${ }^{66}$

\section{Studia filozoficzne}

Przygotowanie filozoficzne przyszłych kapłanów ma szczególne znaczenie ze względu na studium teologii, jak również na konieczność podjęcia owocnego dialogu ze współczesnym człowiekiem. ${ }^{67}$

Jeśli chodzi o przedmioty z zakresu filozofii, szczególną uwagę powinno się poświęcić studium filozofii systematycznej, która prowadzi do gruntownego i spójnego poznania człowieka, świata i Boga, gwarantując obszerną syntezę myśli i światopoglądów. Studium to powinno bazować na wiecznie żywym dziedzictwie filozoficznym, którego świadkami są wielcy filozofowie chrześcijańscy.

$\mathrm{Na}$ tym etapie formacji, odpowiednie miejsce powinno być zarezerwowane dla metafizyki, mając na uwadze, że „charakter mądrościowy filozofii zakłada jej «możliwości autentycznie metafizyczne, to znaczy czyni ją zdolną do wykraczania poza dane empiryczne, aby dojść w swoim poszukiwaniu prawdy, do czegoś absolutnego, ostatecznego, będącego fundamentem», aczkolwiek poznanego stopniowo na przestrzeni czasu" ${ }^{68}$ zgodnie z , "pierwotnym powołaniem» filozofii, którym jest poszukiwanie prawdy oraz jej wymiaru mądrościowego i metafizycznego". ${ }^{69}$ Należy też poświęcić należną uwagę

66 Por. tamże, nr 157.

${ }^{67}$ Por. KK, nr 14-15; PDV, nr 52; J a n P a w e 1 II, Encyklika ,Fides et ratio”, 14 IX 1998, Watykan 1998, nr 60; Congregazione per 1'Educazione C a t t o l i c a, Lettera circolare „L'insegnamento della filosofia nei seminari”, 20 I 1972, Rzym 1972; KPK, kan. 251; B e n e d y k t XVI, List do Seminarzystów, nr 5, s. 6.

${ }^{68} \mathrm{Kongregacja} \mathrm{Edukacji} \mathrm{Katolickiej,Dekreto} \mathrm{reformie} \mathrm{studiów}$ kościelnych filozofii, 28 I 2011, Rzym 2011, nr 4; Ś w i ę t a K o n g re ga c ja E d u k a c j i K a t ol i c k i ej, Nauczanie filozofii w seminariach, 20 I 1972, Rzym 1972.

${ }^{69}$ Kongregacja Edukacji Katoli ckiej, Dekreto reformiestudiów kościelnych filozofii, $\mathrm{nr} 3$. 
teodycei i kosmologii, które wprowadzają w chrześcijańską wizję rzeczywistości.

Według Ratio fundamentalis, z pilnością winna też być nauczana historia filozofii, aby zostały jasno ukazane pochodzenie i rozwój najważniejszych tematów filozoficznych oraz antropologia filozoficzna, logika, estetyka, epistemologia, etyka, filozofia polityczna i filozofia religii. ${ }^{70}$

Ponadto dużą uwagę trzeba zwrócić na nauki humanistyczne, takie jak socjologia, pedagogika i psychologia, w tych aspektach, które zostały uznane za najbardziej przydatne do procesu formacyjnego w perspektywie posługi kapłańskiej. Ich studium ma na celu umożliwienie seminarzystom nabycie zdolności do poznania ducha ludzkiego, wraz z jego bogactwami i słabościami, by tym sposobem ułatwić im formułowanie ocen jasnych i wyważonych dotyczących osób i sytuacji. ${ }^{71}$

\section{Studia teologiczne}

Ratio fundamentalis przypomina, że formacja teologiczna powinna pomóc kandydatowi do kapłaństwa w ,ukształtowaniu własnej wizji prawd objawionych przez Boga w Jezusie Chrystusie i doświadczenia wiary Kościoła, wizji pełnej i scalonej. Z tego wypływa podwójny wymóg, by poznać «wszystkie» prawdy chrześcijańskie, nie wybierając ich arbitralnie, i by je poznać w sposób organiczny". ${ }^{72}$ Należy zatem wspomóc seminarzystę w ,dokonaniu syntezy, ogarniającej wkład różnych dyscyplin teologicznych, których specyfika nabiera autentycznej wartości jedynie w ich głębokim powiązaniu". ${ }^{73}$ Chodzi o etap podstawowy i bardzo ważny formacji intelektualnej, „bowiem przez studium, zwłaszcza teologii, przyszły kapłan wnika

\footnotetext{
70 Por. RFIS, nr 161-162.

71 Por. tamże, nr 163.

72 Tamie, nr 165; PDV, nr 54.

73 Tamże, nr 52.
} 
głęboko w Słowo Boże, wzrasta w życiu duchowym i przygotowuje się do wypełnienia posługi pasterskiej". ${ }^{74}$

Ratio zaleca, aby w programie formacji teologicznej uwzględnić studium Pisma Świętego, liturgii, teologii (dogmatycznej, fundamentalnej, duchowości, moralnej i pastoralnej), patrologii, misjologii, katolickiej nauki społecznej, historii Kościoła, prawa kanonicznego, ekumenizmu, historii religii, języka hebrajskiego i greki biblijnej. ${ }^{75}$

\section{Studium przedmiotów ,stużacych bezpośrednio postudze kapłańskiej"}

Według Ratio, tymi przedmiotami są te, których znajomość wymagana jest przede wszystkim ze względu na specyficzne potrzeby przyszłej posługi duszpasterskiej, ${ }^{76}$ mającej być wykonywaną w konkretnym kontekście czasu i miejsca. Zgodnie z kryteriami, które winno ustalić każde Ratio krajowe, poszczególne seminaria mają zatroszczyć się o zapewnienie seminarzystom ich nauczania w ciągu procesu formacyjnego. ${ }^{77}$

W programie wspomnianych przedmiotów należy uwzględnić studium dotyczące: ars celebrandi, różnych form pobożności ludowej, hagiografii, tematów związanych ze sztuką i muzyką sakralną, zarządzania dobrami kościelnymi, podstawowymi elementami prawa cywilnego w tej materii, środkami komunikacji społecznej. Ponadto seminarzystom winny być zaoferowane kursy mające na celu przygotowanie homilii i wprowadzające w posługę spowiednictwa oraz języka łacińskiego i przynajmniej jednego języka nowożytnego. ${ }^{78}$

\footnotetext{
74 RFIS, nr 165; PDV, nr 51.

75 Por. RFIS, nr 166-175.

76 Por. KPK, kan. 256, § 1.

77 Por. RFIS, nr 176.

78 Por. tamże, nr 177-183.
} 


\section{Studia specjalistyczne}

Ratio fundamentalis zauważa, że oprócz studiów instytucjonalnych, niezbędnych w formacji każdego kapłana, apostolat może wymagać od niektórych specjalnego przygotowania. Abstrahując od możliwości promowania jakiejś specjalizacji w perspektywie działalności duszpasterskiej, ważna jest formacja kapłanów przeznaczonych do wykonywania zadań i pełnienia urzędów wymagających pogłębionego przygotowania, które mogą nabyć przez uczestnictwo w specjalnych kursach. Jako przykład można wymienić kursy przeznaczone do kształcenia pracowników sądów kościelnych, formatorów seminaryjnych, pracowników zajmujących się środkami społecznego przekazu, zarządzaniem dobrami kościelnymi lub katechezą. ${ }^{79}$

\section{Niektóre wskazania dotyczace przygotowania Ordo studiorum}

W Ordo studiorum, stanowiącym część integralną Ratio krajowego i opracowanym przez Konferencję Episkopatu, powinien być zawarty wykaz przedmiotów przewidzianych w formacji intelektualnej na każdym etapie formacyjnym. Winny być też ukazane w sposób zwięzły cele każdego przedmiotu, kontekstualizacja danego przedmiotu w całości nauczania, program studiów, a ponadto rozkład lat i semestrów wraz z liczbą punktów (kredytów) przyznawanych poszczególnym przedmiotom.

Należy mieć na uwadze, że studium przedmiotów propedeutycznych powinno trwać przynajmniej rok. Czas trwania studiów filozoficznych powinien wynosić co najmniej dwa lata lub odpowiadać adekwatnej liczbie godzin semestralnych, przewidzianych przez system nauczania obowiązujący w danym kraju. Studia teologiczne natomiast powinny trwać przynajmniej cztery lata. Tak więc całość studiów filozoficznych i teologicznych winna stanowić przynajmniej sześcioletni okres. ${ }^{80}$

79 Por. tamże, nr 185.

80 Por. KPK, kan. 250. 
Przedmioty, które Ratio fundamentalis przedstawia w ramach studiów propedeutycznych, filozoficznych i teologicznych, oraz te „służące bezpośrednio posłudze kapłańskiej”, winny tworzyć strukturę zasadniczą studiów w seminariach oraz we wszystkich domach formacyjnych. Będą one mogły być uzupełnione przez Konferencję Episkopatu, mając na uwadze lokalną tradycję formacyjną i specyficzne potrzeby duszpasterskie. ${ }^{81}$

\section{Wymiar duszpasterski}

Formacja duszpasterska stanowi ukoronowanie całej formacji kapłańskiej. Prawda ta została potwierdzona już w soborowym dekrecie Optatam totius: „Kształcenie (...) alumnów powinno w całości zmierzać do tego, by stawali się oni prawdziwymi duszpasterzami na wzór Pana naszego Jezusa Chrystusa, Nauczyciela, Kapłana i Pasterza". ${ }^{82}$ Również Jan Paweł II zauważył, że: „Cel duszpasterski (...) integruje i kształtuje całą formację przyszłych kapłanów". ${ }^{83}$

W tym samym duchu ukazuje cel integralnej formacji kapłańskiej przyszłych kapłanów aktualne Ratio fundamentalis. Do jego realizacji konieczne jest studium przez seminarzystów teologii pastoralnej korzystającej tam, gdzie to niezbędne, z cennego wkładu nauk humanistycznych, szczególnie psychologii, pedagogiki i socjologii, oraz wykonywanie przez nich praktyk o charakterze apostolskim. ${ }^{84}$

Praktyki kandydatów do kapłaństwa winny być dostosowane do ich wieku i zdolności oraz być wykonywane w odpowiednich okresach, zwłaszcza poza wykładami akademickimi i w formach najbardziej stosownych. Dużą uwagę należy zwrócić na środowiska, w których będą one pełnione. Urzywilejowanym miejscem powinna być parafia. Ponadto należy zadbać o przygotowanie seminarzystów do specyficznego towarzyszenia duszpasterskiego rodzinom,

\footnotetext{
81 Por. RFIS, nr 154.

$82 \mathrm{KK}, \mathrm{nr} 4$.

83 PDV, nr 57.

84 Por. RFIS, nr 122.
} 
dzieciom, młodzieży, chorym, ludziom w podeszłym wieku, osobom niepełnosprawnym, więźniom oraz żyjącym w samotności lub biedzie.

Wspomniane praktyki duszpasterskie winny być wykonywane przez kandydatów do kapłaństwa pod kierownictwem kapłanów, osób konsekrowanych i ludzi świeckich, będących prawdziwymi i rozważnymi ekspertami. Osoby te powinny przydzielić każdemu seminarzyście określone zadania i pouczyć o sposobie wykonywania. Powinny też być możliwie obecne w czasie wypełniania przez niego powierzonych zadań, by mu doradzić, wesprzeć i odpowiednio pomóc w ocenie ich realizacji. ${ }^{85}$

\section{Dogłębne rozeznanie zdatności kandydatów do kapłaństwa}

Aktualna i bardzo złożona sytuacja młodzieży wymaga od biskupa i formatorów seminaryjnych dogłębnego rozeznania zdatności kandydatów do kapłaństwa w momencie ich przyjmowania do seminarium oraz promocji do święceń.

Kodeks Prawa Kanonicznego przypomina w tym względzie: „Do wyższego seminarium biskup diecezjalny powinien przyjmować jedynie tych, którzy, biorąc pod uwagę ich przymioty ludzkie i moralne, duchowe i intelektualne, ich zdrowie fizyczne i psychiczne, jak również szczerą wolę, wydają się zdolni do oddania się na stałe świętym posługom”. ${ }^{86}$ Jednocześnie tenże Kodeks stanowi: „Do święceń należy dopuszczać jedynie tych, którzy - według roztropnej oceny własnego biskupa albo kompetentnego przełożonego wyższego - po rozważeniu wszystkich okoliczności, mają nieskażoną wiarę, kierują się prawidłową intencją, posiadają wymaganą wiedzę, cieszą się dobrą opinią, mają nienaganne obyczaje, wypróbowane cnoty, jak również inne przymioty fizyczne i psychiczne, odpowiadające przyjmowanemu święceniu". ${ }^{87}$

\footnotetext{
85 Por. tamże, nr 124.

86 KPK, kan. 241, § 1 .

87 Tamże, kan. 1029.
} 


\section{Zdrowie fizyczne i psychiczne}

Według Ratio fundamentalis, zgodnie z właściwymi normami wydanymi przez Konferencję Episkopatu i załączonymi do Ratio krajowego, w momencie wstępowania do seminarium seminarzysta będzie musiał wykazać się posiadaniem kondycji zdrowotnej dającej się pogodzić z przyszłą posługą kapłańską. W sposób szczególny będzie zobowiązany do przedstawienia wyników ogólnych badań lekarskich, gwarantujących dobry stan zdrowia, oraz ewentualnej dokumentacji dotyczącej chorób, przebytych operacji i poszczególnych terapii z przeszłości. Zawartość tejże dokumentacji może być znana jedynie biskupowi i rektorowi seminarium diecezjalnego, a jej rozpowszechnienie będzie regulowane prawem cywilnym i kościelnym, które obowiązują w danym kraju.

Ratio podkreśla, że w tym zakresie należy wziąć pod uwagę to, co zostało zarządzone przez Kongregację Nauki Wiary jeśli chodzi o roztropną i indywidualną ocenę tych, którzy są chorzy na celiakię albo dotknięci alkoholizmem lub podobnymi chorobami W związku z tym, co zostało przedstawione przez tę dykasterię odnośnie do innych sytuacji zdrowotnych, które mogłyby zaszkodzić wykonywaniu posługi kapłańskiej, powierza się Konfrencji Episkopatu wypracowanie właściwych norm. Odpowiednia kondycja zdrowotna powinna być trwała i może być weryfikowana przez cały okres formacji. ${ }^{88}$

Jeśli chodzi o zdrowie psychiczne, Ratio stanowi, że z reguły należy unikać przyjmowania do seminarium osób, które cierpią na jakąkolwiek patologię, postrzegalną lub ukrytą (np. schizofrenię, paranoję, zaburzenie bipolarne, zaburzenie preferencji seksualnych itd.), w stopniu mogącym osłabić zdolność rozeznania oceniającego przez tę osobę, i w konsekwencji jej zdolność do podjęcia zadań wynikających z powołania i posługi. ${ }^{89}$

88 Por. RFIS, nr 190; por. także K ong re ga c j a N a u k i W i a r y, Listy okólne z 19 czerwca 1995 r. i z 24 lipca 2003 r.

89 Por. RFIS, nr 191. 
Dokument kongregacji wspomina o możliwości dokonania oceny psychologicznej kandydata do kapłaństwa w momencie przyjmowania do seminarium, jak również później, gdy formatorzy uznają to za użyteczne. Zauważa się jednak w nim, że aby formatorzy mogli się zwrócić do specjalisty w zakresie nauk psychologicznych o dokonanie wspomnianej oceny, konieczna jest ze strony seminarzysty uprzednia, świadoma i dobrowolna zgoda wyrażona na piśmie. ${ }^{90}$ Z drugiej zaś strony w Ratio przypomina się, że „,kandydat do prezbiteratu nie może narzucać własnych osobistych warunków, lecz musi zaakceptować z pokorą i wdzięcznością normy i warunki, które Kościół w duchu odpowiedzialności wyznacza ze swej strony”. ${ }^{91} \mathrm{Ze}$ względu na ochronę własnej intymności „kandydat może zwrócić się w sposób wolny do eksperta wybranego spośród wskazanych przez formatorów lub do wybranego przez siebie i zaakceptowanego przez nich. W miarę możliwości powinna być zawsze zagwarantowana kandydatom wolność wyboru spośród specjalistów, którzy będą spełniali określone wymagania". ${ }^{92}$

Po zredagowaniu relacji, przestrzegając obowiązującego prawa cywilnego, biegły ma obowiązek poinformowania o wynikach swoich badań osobę bezpośrednio zainteresowaną i jedynie niektóre osoby upoważnione do poznania tych danych ze względu na wykonywany przez nich urząd: „Po dokonaniu badania, uwzględniając także wskazania formatorów, ekspert jedynie za uprzednią zgodą kandydata wyrażoną na piśmie, przekaże im swoje wyniki badań dla zrozumienia rodzaju osobowości kandydata oraz problemów, które on przeżywa lub którym musi stawić czoło. Wskaże on także,

90 Por. tamże, nr 194; K o ng rega cja Eduka cji Katolickiej, Wskazania dotyczace wykorzystania nauk psychologicznych $w$ przyjmowaniu i formacji kandydatów do kapłaństwa, 29 VI 2008, Rzym 2008, nr 12, 15.

91 RFIS, nr 194; K ongre ga c ja Eduka c j i Katolickiej, Wskazania dotyczace wykorzystania nauk psychologicznych $w$ przyjmowaniu i formacji kandydatów do kapłaństwa, nr 11.

92 RFIS, nr 194; Kongregacja Edukacji Katolickiej, Wskazania dotyczace wykorzystania nauk psychologicznych w przyjmowaniu i formacji kandydatów do kapłaństwa, nr 12. 
zgodnie z własną oceną oraz posiadanymi kompetencjami, możliwości rozwoju osobowości kandydata, które są do przewidzenia. Ponadto powinien zasugerować, jeśli to konieczne, formy i środki pomocy psychologicznej". ${ }^{93}$ Biorąc pod uwagę powyższe wskazania, osobami upoważnionymi do zapoznania się z informacjami przekazanymi przez biegłego są: biskup (diecezji zainteresowanego oraz diecezji odpowiedzialnej za seminarium, jeśli jest inna), rektor (seminarium, w którym odbywa się formacja oraz seminarium diecezjalnego, jeśli są one różne) i kierownik duchowy. ${ }^{94}$

Do każdej Konferencji Episkopatu należy wydanie norm do włączenia w Rationes krajowe, które ustalą sposób przeprowadzania badań psychologicznych, jak również czas przechowywania dokumentów dotyczących zdrowia fizycznego i psychicznego seminarzystów, zgodnie z obowiązującym prawem cywilnym w danym kraju, mając na uwadze możliwe konsekwencje, także karne, związane z rozpowszechnieniem, choćby nieświadomym, danych zawartych w tejże dokumentacji. ${ }^{95}$

\section{Seminarzyści pochodzący z innych seminariów}

lub instytutów formacji

Ratio fundamentalis podkreśla z całą stanowczością, że jest konieczne, aby ten, kto po usunięciu lub opuszczeniu seminarium prosi o przyjęcie do nowego seminarium lub domu formacyjnego, przedstawił na piśmie prośbę do biskupa, opisując własną drogę życia oraz motywy, które doprowadziły w przeszłości do usunięcia go lub opuszczenia innego instytutu formacji. Rektor seminarium, do którego dana osoba pragnie być przyjęta, nie może uchylić się od uzyskania dokumentacji, także o charakterze psychologicznym,

93 RFIS, nr 195; Kongregacja Edukacji Katolickiej, Wskazania dotyczace wykorzystania nauk psychologicznych $w$ przyjmowaniu i formacji kandydatów do kapłaństwa, $\mathrm{nr} 15$.

94 Por. RFIS, nr 195.

95 Por. tamże, nr 196. 
odnoszącej się do czasu, w którym dana osoba przebywała w innym centrum formacji, ${ }^{96}$ zgodnie ze wskazaniami Konferencji Episkopatu. ${ }^{97} \mathrm{Na}$ ogół chodzi o sytuacje bardzo delikatne, które wymagają od formatorów dodatkowego starannego rozeznania oraz bardzo wielkiej roztropności przed ewentualnym przyjęciem kandydata do seminarium.

\section{Osoby o tendencjach homoseksualnych}

W przypadku osób o tendencjach homoseksualnych, które usiłują wstąpić do seminariów lub które podczas formacji odkrywają taką skłonność, Ratio fundamentalis, odwołując się do już istniejących norm w tej kwestii, przypomina, że Kościół w zgodzie z własnym nauczaniem ${ }^{98}$,głęboko szanując osoby, których dotyczy ten problem, nie może przyjmować do seminarium ani do święceń osób, które praktykują homoseksualizm, wykazują głęboko zakorzenione tendencje homoseksualne lub wspierają tak zwaną «kulturę gejowską». Osoby takie, w istocie, znajdują się w sytuacji, która poważnie uniemożliwia im poprawną relację do mężczyzn i kobiet. Nie można w żaden sposób zignorować negatywnych konsekwencji mogących zrodzić się na skutek święceń osób o głęboko zakorzenionych tendencjach homoseksualnych". ${ }^{99}$ „Inaczej natomiast należałoby traktować tendencje homoseksualne, które są jedynie wyrazem przejściowego problemu, jak na przykład, nie zakończony jeszcze

96 Por. tamże, nr 198; por. także, KPK, kan. 241, § 3; K o n g r e g a c ja E d u k a c j i K a tol i c k i e j, Wskazania dotyczace wykorzystania nauk psychologicznych w przyjmowaniu i formacji kandydatów do kapłaństwa, nr 16.

97 Por. t a ż, Instrukcje dla Konferencji Episkopatów na temat przyjmowania do seminarium kandydatów pochodzacych z innych seminariów lub rodzin zakonnych, Rzym, 19 III 1985, 8 III 1996.

98 Por. RFIS, nr 199; por. także Katechizm Kościoła Katolickiego, nr 2357-2358.

99 RFIS, nr 199; Kongrega cja E duka c ji Katolickiej, Instrukcja dotyczaca kryteriów rozeznawania powołania u osób z tendencjami homoseksualnymi ubiegajacych się o przyjęcie do seminarium i dopuszczenie do święceń, 4 XI 2005, Rzym 2005, nr 2. 
proces dojrzewania. Niemniej jednak, takie tendencje muszą być wyraźnie przezwyciężone, przynajmniej trzy lata przed święceniami diakonatu". ${ }^{100}$

Ratio fundamentalis zobowiązuje seminarzystę, aby w szczerym dialogu i wzajemnym zaufaniu zakomunikował biskupowi, rektorowi, kierownikowi duchowemu i innym wychowawcom, ewentualne wątpliwości lub trudności w tejże kwestii. ${ }^{101}$

W tym też kontekście dokument kongregacji przypomina, że „jeśli kandydat uprawia homoseksualizm albo wykazuje głęboko zakorzenione tendencje homoseksualne, jego kierownik duchowy, a także spowiednik ma w sumieniu obowiązek odwieść go od ubiegania się o święcenia”. ${ }^{102} \mathrm{~W}$ każdym razie „byłoby poważną nieuczciwością, gdyby kandydat ukrywał swój własny homoseksualizm, aby pomimo wszystko ubiegać się o święcenia kapłańskie. Taka nieszczera postawa nie odpowiada duchowi prawdy, lojalności i dyspozycyjności, który musi cechować osobowość tego, kto uważa, że jest powołany do służby Chrystusowi i Jego Kościołowi w posłudze kapłańskiej". ${ }^{103}$

Według Ratio, nie można ukrywać przed seminarzystami, że „samo pragnienie bycia kapłanem nie wystarczy; nie istnieje także prawo do otrzymania święceń. Do Kościoła należy (...) rozeznanie zdatności tego, który pragnie wstąpić do seminarium, towarzyszenie mu w latach jego formacji oraz dopuszczenie go do święceń, jeśli uznany zostanie za posiadającego niezbędne przymioty". ${ }^{104}$

${ }^{100}$ RFIS, nr 200; Kong rega c ja E d u k a c ji Katoli c k i e j, Instrukcja dotyczaca kryteriów rozeznawania powołania u osób z tendencjami homoseksualnymi ubiegających się o przyjęcie do seminarium i dopuszczenie do święceń, nr 2.

101 Por. RFIS, nr 200.

${ }^{102}$ Tamże; Kongrega c ja E du k a c j i Katoli ck i e j, Instrukcja dotycząca kryteriów rozeznawania powołania u osób z tendencjami homoseksualnymi ubiegających się o przyjęcie do seminarium i dopuszczenie do święceń, nr 3.

${ }^{103}$ Tamże.

${ }^{104}$ Tamże. 
Ochrona niepełnoletnich i towarzyszenie ofiarom

Obecne Ratio fundamentalis zaleca wreszcie, aby bardzo dużą uwagę poświęcić ochronie niepełnoletnich oraz osób dorosłych słabych i bezbronnych, czuwając z troską nad tym, aby ci, którzy zwracają się z prośbą o przyjęcie do seminarium lub domu formacyjnego, lub proszą już o przyjęcie sakramentu święceń, nie byli w jakikolwiek sposób powiązani z przestępstwami lub sytuacjami dotyczącymi nadużyć w tej kwestii.

Formatorzy winni zapewnić szczególne i odpowiednie towarzyszenie osobom, które doświadczyły w swoim życiu bolesnych sytuacji w tym zakresie.

Dokument kongregacji zaleca, aby zarówno do programu formacyjnego początkowego, jak i stałego, zostały włączone specyficzne zajęcia, seminaria lub kursy o ochronie niepełnoletnich. Powinny też być stosownie przekazane odpowiednie informacje, dotyczące możliwego wykorzystywania i przemocy, jak na przykład handlu niepełnoletnimi, pracy niepełnoletnich oraz wykorzystywania seksualnego ich oraz osób dorosłych słabych i bezbronnych. ${ }^{105}$

$$
* * *
$$

Podsumowując, należy zauważyć, że Kongregacja ds. Duchowieństwa w opublikowanym Ratio fundamentalis institutionis sacerdotalis, przedstawiającym aktualne wytyczne dotyczące formacji przyszłych kapłanów, wykorzystała treści, metody, wskazania już istniejące w tej dziedzinie, uaktualniając je oraz wzbogacając o nowe. Dokument Kongregacji, oprócz znanego już nazewnictwa, które dzieliło drogę formacyjną na „etap studiów filozoficznych”, ,etap studiów teologicznych" i „etap pastoralny” dodał ,etap bycia uczniem”, „etap upodabniania się do Chrystusa” i „etap syntezy powołaniowej”, którym odpowiada droga i treści formacyjne, ukierunkowane na upodabnianie kandydata na obraz Jezusa Chrystusa Dobrego Pasterza.

${ }^{105}$ Por. RFIS, nr 202. 
Ratio ukazuje jasno, że seminarzysta, aby mógł zostać dobrym kapłanem, oprócz zdania wszystkich egzaminów, przewidzianych przez Ordo studiorum, powinien posiadać dowiedzioną dojrzałość ludzką, duchową i duszpasterską. Może stanowić pomocne narzędzie w formowaniu kapłanów, którzy będą namaszczonymi pasterzami dla Ludu Bożego, mającymi dla niego serce Chrystusa współczujące i miłosierne.

ks. Ryszard SELEJDAK

Słowa kluczowe: Ratio fundamentalis institutionis sacerdotalis, Ratio krajowe, kapłaństwo powszechne wiernych, kapłaństwo służebne, tożsamość kapłańska, seminarzyści, formatorzy, formacja integralna, formacja początkowa i permanentna, ludzki, duchowy, intelektualny i duszpasterski wymiar formacji, studia specjalistyczne

Keywords: Ratio Fundamentalis Institutionis Sacerdotalis, Ratio Nationalis, Ordo Studiorum, common priesthood of the faithful, ministerial priesthood, priestly identity, seminarians, formators, integrated formation, initial and ongoing formation, human, spiritual, intellectual and pastoral dimensions of formation, specialised studies

\section{Formation of Candidates for the Priesthood in Light of the New Ratio Fundamentalis Institutionis Sacerdotalis}

Summary

The last Ratio Fundamentalis Institutionis Sacerdotalis was published in 1970 and updated in 1985. In the meantime, and particularly under the effect of the rapid changes in the modern world, the historical, socio-cultural and ecclesial contexts have changed, in which the priest is called to make manifest the mission of Christ and the Church. This has also led to significant changes in related matters: the image or the view of the priest, the spiritual needs of the People of God, the challenges of the new evangelisation, and the languages of communication, to name just a few. In this situation, it seemed that priestly formation needed to be relaunched, renewed and returned 
to the centre. On 8 December 2016, therefore, the Congregation for the Clergy published the new Ratio Fundamentalis Institutionis Sacerdotalis, a tool for the formation of priests. It has taken up the contents, methods and approaches presented so far in the field of formation, updating them and introducing new elements. The document restates the guidelines offered in the Apostolic Exhortation Pastores Dabo Vobis regarding an integrated formation of seminarians. In this formation, the formators and professors are called to demonstrate the close relationship between theology, the spiritual life and the pastoral ministry. This is so in order that the candidate for the priesthood might become a good shepherd of the People of God and have a compassionate and merciful heart like Christ. 